\title{
Species-specific effects of two bioturbating polychaetes on sediment chemoautotrophic bacteria
}

\author{
Diana Vasquez-Cardenas ${ }^{1, *}$, Cintia Organo Quintana ${ }^{2}$, Filip J. R. Meysman ${ }^{1,3}$, \\ Erik Kristensen $^{2}$, Henricus T. S. Boschker ${ }^{1}$ \\ ${ }^{1}$ Netherlands Institute for Sea Research (NIOZ), Korringaweg 7, 4401NT Yerseke, Netherlands \\ ${ }^{2}$ Department of Biology, University of Southern Denmark, Campusvej 55, 5230 Odense M, Denmark \\ ${ }^{3}$ Department of Environmental, Analytical and Geo-Chemistry, Vrije Universiteit Brussel (VUB), Pleinlaan 2, \\ 1050 Brussels, Belgium
}

\begin{abstract}
Bioturbation has major impacts on sediment biogeochemistry, which can be linked to the functional traits of the macrofauna involved. Nereis (Hediste) diversicolor and Marenzelleria viridis are 2 functionally different bioturbating polychaetes that strongly affect the ecology and biogeochemistry of coastal sediments. However, the different effects of these polychaetes on the activity and composition of microbial communities and on chemoautotrophic bacteria have not been extensively studied. We performed experiments with sediment aquaria that contained each species separately as well as a non-bioturbated control. Bacterial communities in different sediment zones (surface, burrow, subsurface) were characterized by phospholipid-derived fatty acid analysis combined with stable isotope labeling $\left({ }^{13} \mathrm{C}\right.$ bicarbonate) to quantify the dark $\mathrm{CO}_{2}$ fixation by chemoautotrophic bacteria. Pore water chemistry ( $\Sigma \mathrm{H}_{2} \mathrm{~S}$ and dissolved inorganic carbon) was additionally assessed in each treatment. The strong ventilation but low bioirrigation capacity in the open-ended burrows of $N$. diversicolor resulted in enhanced aerobic chemoautotrophic activity, potentially by sulfur oxidizing and nitrifying bacteria along the burrow. In contrast, slower ventilation and higher irrigation by $M$. viridis induced an advective mode of pore water transport. This promotes anaerobic chemoautotrophy around the blind-ended burrow and within the subsurface sediment. Sulfate-reducing bacteria were the dominant anaerobic chemoautotrophs that probably disproportionate sulfur. In conclusion, our analysis shows that bioturbating fauna influence the microbial community and chemoautotrophic activity in sediments, but that the effect strongly depends on the structure of the burrow and on species-specific ventilation behavior and irrigation capacity.
\end{abstract}

KEY WORDS: Dark carbon fixation · Fatty acids · Stable isotope probing $\cdot$ PLFA · Microbes · Nereis (Hediste) diversicolor · Marenzelleria viridis

\section{INTRODUCTION}

Ideally, marine sediments are characterized by a predictable vertical zonation of electron donors and acceptors, but in the presence of benthic fauna this typical 1-dimensional redox zonation is disturbed through particle reworking and solute transport induced by burrow formation and ventilation, a process known as bioturbation (Aller 1988, Meysman et al.

*Corresponding author: diana.vasquez@nioz.nl
2006, Kristensen et al. 2012). Bioturbation creates steep chemical gradients along burrows, which may modify the spatial distribution of various microbial metabolic pathways such as sulfate reduction, sulfide oxidation, denitrification and nitrification (Aller 1988, Kristensen \& Kostka 2005, Bertics \& Ziebis 2010). The manner in which chemical gradients and, subsequently, microbial assemblages vary in the sediment has been linked to the functional traits of the biotur-

(C) The authors 2016. Open Access under Creative Commons by Attribution Licence. Use, distribution and reproduction are unrestricted. Authors and original publication must be credited. 
bating fauna such as burrow properties (e.g. shape, depth and residence time), ventilation behavior, feeding habits and/or sediment mixing intensity (Marinelli et al. 2002, Papaspyrou et al. 2006, Bertics \& Ziebis 2009, Laverock et al. 2010, Gilbertson et al. 2012). Bioturbation therefore has a major impact on sediment biogeochemistry, which differs depending on the ecology and behavior of the macrofaunal organisms involved (Braeckman et al. 2010, Mermillod-Blondin 2011, Kristensen et al. 2014).

Nereis (Hediste) diversicolor and Marenzelleria viridis are 2 burrow-dwelling polychaetes that have contrasting effects on the ecosystem functioning of coastal areas in the Baltic Sea (Kristensen et al. 2014). Both species are surface deposit feeders, but $N$. diversicolor is also a suspension feeder (Christensen et al. 2000). In regard to bioturbation activities, both $N$. diversicolor and $M$. viridis promote a limited amount of particle reworking, which consists of a random downward transport of sediment particles over short distances, known as gallery biodiffusion (Kristensen et al. 2012). However, the burrow morphology and ventilation mode (i.e. flushing of the burrow with oxygenated water) differ strongly between the 2 polychaetes, inducing distinct modes of bioirrigation (i.e. biologically enhanced transport of pore water and solutes) that create divergent geochemical conditions. $N$. diversicolor inhabits a mucus-lined open-ended burrow (typically U- or Y-shaped, up to $20 \mathrm{~cm}$ deep) that is regularly flushed by undulatory body movements (Kristensen \& Kostka 2005). This intense burrow ventilation results in diffusion-based radial solute transport into the surrounding sediment pore water, but creates only limited advective pore water movement in the surrounding sediment (Pischedda et al. 2012, Kristensen et al. 2014). N. diversicolor has more than twice as much oxygenated sediment surrounding its burrows as $M$. viridis $\left(5 \mathrm{~cm}^{3}\right.$ versus $1.8 \mathrm{~cm}^{3}$, respectively), creating more oxidized conditions in deeper sediments (Kristensen et al. 2011, Jovanovic et al. 2014) and heterogenous conditions which appear to promote high microbial diversity (Pischedda et al. 2011). In contrast, $M$. viridis creates deep burrows (up to $30 \mathrm{~cm}$ deep) that are typically straight down and blindended. $M$. viridis ventilates its burrow slowly through ciliar and muscular movements that promote advective flow of anoxic pore water in the surrounding sediment (Kristensen et al. 2011, Quintana et al. 2011, Jovanovic et al. 2014). M. viridis activity therefore simultaneously maintains reduced conditions in the deeper sediment that stimulate sulfate reduction, while potentially enhancing sulfide oxidation in sur- face sediments, given the upward flow of solutes (Quintana et al. 2007, Kristensen et al. 2011, 2014).

The distinct impacts of $N$. diversicolor and $M$. viridis on the sediment geochemistry suggest substantial differences in the bacterial community composition and function. One microbial metabolism considered to be affected by bioturbation is chemoautotrophy, given the steep chemical gradients and the potential overlap of electron acceptors and donors along the burrow structure (Aller 1988, Kristensen \& Kostka 2005). Burrow walls are ideal environments for chemoautotrophic bacteria that fix inorganic carbon by obtaining energy from the oxidization of reduced compounds (e.g. sulfide, ammonium) produced in the sediment. The specific effects of bioturbation on the microbial community composition have occasionally been studied (Steward et al. 1996, Papaspyrou et al. 2006, Cuny et al. 2007, Kunihiro et al. 2011, Yazdani Foshtomi et al. 2015), including only 1 study that quantified the impact on the growth of chemoautotrophic bacteria (Reichardt 1988). The latter study found a substantial increase of dark $\mathrm{CO}_{2}$ fixation along the burrow of the lugworm Arenicola marina when compared to the surface sediment. Therefore, we expect enhanced chemoautotrophic activity along the burrows of $N$. diversicolor and $M$. viridis compared to the adjacent sediment. However, given the contrasting functional traits of these 2 polychaete species, we hypothesize that the bacterial community in these burrow environments could be species-specific. To test this hypothesis, we used phospholipid-derived fatty acid analysis combined with stable isotope probing (PLFA-SIP). This approach allows simultaneous characterization of the total bacterial and chemoautotrophic community composition as well as the quantification of dark $\mathrm{CO}_{2}$ fixation rates (Boschker et al. 2014). We also determined the effects of polychaetes on sediment pore water chemistry. The impact on chemoautotrophic activity and differences in microbial composition were then linked to the functional traits of $N$. diversicolor and $M$. viridis.

\section{MATERIALS AND METHODS}

\section{Experimental set-up}

Sediment incubations were performed consisting of the following 3 treatments: with addition of Nereis (Hediste) diversicolor (Nd); with addition of Marenzelleria viridis $(\mathrm{Mv})$; and without addition of polychaetes (Control). Sediment (top $25 \mathrm{~cm}$ ), polychaetes 
and overlying water for incubations were collected at Bregnør Bay, Denmark $\left(55.481^{\circ} \mathrm{N}, 10.610^{\circ} \mathrm{E}\right)$, in September 2012 (water depth: $50 \mathrm{~cm}$, water temperature: $18^{\circ} \mathrm{C}$, salinity: 20 ). The sediment at the sampling location is described as organic-poor median sand with a porosity of $0.40 \pm 0.03$ (Quintana et al. 2007, Jovanovic et al. 2014). Sediment was gently sieved at the location through a $1 \mathrm{~mm}$ mesh and later homogenized in the laboratory. Active individuals of $M$. viridis and $N$. diversicolor were collected for experiments during sieving, and were kept in buckets with aerated seawater $\left(15^{\circ} \mathrm{C}\right)$ and a thin layer of sieved sediment.

For the sediment incubations, we used flat aquaria (height: $35 \mathrm{~cm}$, length: $20 \mathrm{~cm}$, width: $1 \mathrm{~cm}$ ) with 1 removable side panel which was adapted with injection ports distributed on a 2-dimensional grid (distance of $2 \mathrm{~cm}$ between ports). Before assembling the flat aquaria, plastic foil was placed against the inside wall of the removable side panel. This decreased the disturbance of the sediment when the aquarium was opened. A total of 10 aquaria ( $\mathrm{Nd}$ : $3, \mathrm{Mv}$ : 3 and Control: 4) were filled with homogenized sediment to obtain a $\sim 28 \mathrm{~cm}$ sediment depth layer. Aquaria were wrapped in aluminum foil so that only the sediment surface was exposed to light, limiting the development of photosynthetic communities along the walls of the aquaria during incubation. Aquaria were submerged into $90 \mathrm{l}$ water tanks filled with in situ seawater at $16 \pm 2^{\circ} \mathrm{C}$ and exposed to $12 \mathrm{~h}$ light: $12 \mathrm{~h}$ dark cycles for $7 \mathrm{~d}$. Water circulation in the flat aquaria was ensured by aerating each aquarium separately with air pumps and using tubing adapted with needles.

Polychaetes were weighed and transferred to the aquaria after a $24 \mathrm{~h}$ settling period of the sediment. Only motile, visibly undamaged individuals were used in the experiments. Average wet weight was $0.11 \pm 0.02 \mathrm{~g}$ for $N$. diversicolor $(\mathrm{n}=3)$ and $0.37 \pm$ $0.03 \mathrm{~g}$ for $M$. viridis $(\mathrm{n}=3)$. Only 1 individual was added to each flat aquarium to facilitate the identification and collection of burrow sediment for further analysis. The resulting faunal densities (500 ind. $\mathrm{m}^{-2}$ ) were within the range of 14 to 3013 ind. $\mathrm{m}^{-2}$ for $N$. diversicolor and 0 to 1174 ind. $\mathrm{m}^{-2}$ for $M$. viridis observed in Odense Fjord by Delefosse et al. (2012).

\section{Biomarker analysis}

Six days after the addition of individual polychaetes to the flat aquaria we evaluated the effect of bioturbation on the microbial composition and chemoautotrophic activity by analyzing the PLFASIP (Boschker et al. 1998). First, we employed PLFA fingerprinting, which allows the study of the composition and abundance of the total bacterial community. Second, the composition of the chemoautotrophic community and its activity (i.e. dark $\mathrm{CO}_{2}$ fixation rate) was characterized by the incorporation of ${ }^{13} \mathrm{C}$-labeled dissolved inorganic carbon (DIC) into bacterial PLFA. A stock solution of ${ }^{13} \mathrm{C}$ sodium bicarbonate of $60 \mathrm{mM}\left(99 \%{ }^{13} \mathrm{C}_{i}\right.$ Cambridge Isotope Laboratories) was prepared in artificial seawater free of $\mathrm{Ca}^{2+}$ and $\mathrm{Mg}^{2+}$ to prevent carbonate precipitation. Shortly before use, the bicarbonate solution was bubbled with $\mathrm{N}_{2}$ in order to remove the $\mathrm{O}_{2}$. The line injection method (Jørgensen 1978) was used to introduce ${ }^{13} \mathrm{C}$-labeled substrate into the sediment. The substrate was injected through the ports in the side wall of the aquaria in $20 \mu \mathrm{l}$ aliquots from the bottom to the top. Finally, $180 \mu \mathrm{l}$ substrate was added to the $\sim 2 \mathrm{~cm}$-thick layer of overlying water. The top of the aquaria was covered with Parafilm to prevent evaporation and then returned to the water tanks $(16 \pm$ $2{ }^{\circ} \mathrm{C}$ ). The aquaria were kept elevated above the water line to prevent mixing of overlying water with tank water. Overlying water was bubbled with ${ }^{13} \mathrm{C}$ $\mathrm{CO}_{2}$ saturated air to avoid stripping of the label from the overlying water during incubations, as described by Vasquez-Cardenas et al. (2015). Incubations were performed in the dark to exclude ${ }^{13} \mathrm{C}$ incorporation by photosynthetic microorganisms. Of the 4 Control aquaria, 2 did not receive ${ }^{13} \mathrm{C}$ substrate and were used to measure the natural abundance $\delta^{13} \mathrm{C}$.

Stable isotope labeling was terminated after $45 \mathrm{~h}$. Overlying water was removed with a syringe and the sediment surface was examined to locate burrow openings. Aquaria were then placed on their side and the lateral panel was removed. For Nd treatments, more than one burrow was present, so in those cases only the burrow containing the polychaete was considered. The coloration of the sediment surrounding the burrow, burrow diameter and length were recorded. The burrow sediment was defined as the $3 \mathrm{~mm}$-thick layer surrounding the burrow wall. In the $\mathrm{Nd}$ cases, the burrow sediment also included the mucoid burrow lining. The sediment from the active burrows was collected with a sterile spatula. Organisms were carefully extracted from their burrows using pincers. The remaining sediment matrix in the aquaria was then sectioned in horizontal layers of $0.5 \mathrm{~cm}$ intervals in the top $1 \mathrm{~cm}$, followed by $1 \mathrm{~cm}$ intervals to $4 \mathrm{~cm}$ depth, and $2 \mathrm{~cm}$ intervals to $18 \mathrm{~cm}$ depth. The following 4 sediment zones were selected to compare the effects of the burrowing activity on 
the PLFA fingerprint and ${ }^{13} \mathrm{C}$-labeling of the microbial community: burrow (sampled as explained above), surface (0 to $0.5 \mathrm{~cm})$, shallow subsurface $(2$ to $4 \mathrm{~cm}$ ) and deep subsurface (12 to $14 \mathrm{~cm}$ ) (Fig. 1). Sediment was collected in pre-weighed $50 \mathrm{ml}$ double centrifuge tubes and placed on ice until further processing. The bottom of the inner tube was equipped with a GF/C filter to facilitate the collection of pore water. Tubes with sediment were centrifuged at $500 \times g(1500 \mathrm{rpm})$ for $15 \mathrm{~min}$ and pore water was collected from the outer tube, while the sediment in the inner tube was frozen overnight and subsequently lyophilized.

PLFA extractions were performed on dry sediment according to Guckert et al. (1985) and Boschker et al. (1998), and analyzed by gas chromatography with isotope ratio mass spectrometry (GC-IRMS; Thermo) on an apolar analytical column (ZB5-MS Phenomenex). The precision of the GC-IRMS is $\sim 0.3 \%$ $\delta^{13} \mathrm{C}$, which corresponds to a variation in ${ }^{13} \mathrm{C}$ content of $\sim 0.0003 \%$ (Boschker \& Middelburg 2002). PLFA concentrations are expressed in carbon units (nmol C-PLFA [ $g$ dry $w t]^{-1}$ ). Total bacterial biomass was determined as the sum of the concentrations of all bacterial fatty acids (C12:0 to C20:0) converted to biomass, assuming PLFAs constitute $5.5 \%$ of the carbon present in the total bacterial carbon biomass (Middelburg et al. 2000). Sediment dry wt was converted to bulk sediment volume using a dry sediment density of $2.55 \mathrm{~g}$ dry wt $\mathrm{cm}^{-3}$ and the measured sediment porosity (see 'Pore water analysis'). Characterization of the chemoautotrophic community was based on ${ }^{13} \mathrm{C}$ incorporation into PLFA. Briefly, PLFA ${ }^{13} \mathrm{C}$-label incorporation per unit of bulk sediment (pmol ${ }^{13} \mathrm{C} \mathrm{cm}^{-3}$ ) is calculated as the product of each bacterial PLFA concentration and its ${ }^{13} \mathrm{C}$ fraction after labeling (corrected for natural ${ }^{13} \mathrm{C}$ fraction of unlabeled samples). Dark $\mathrm{CO}_{2}$ fixation rates (nmol C $\mathrm{cm}^{-3} \mathrm{~d}^{-1}$ ) were calculated by summation of the PLFA incorporation data for each sediment sample, which was then converted to total biomass incorporation and divided by the length of the incubation period. Dark $\mathrm{CO}_{2}$ fixation rates were corrected for $\delta^{13} \mathrm{C}$ DIC values in pore water relative to natural $\delta^{13} \mathrm{C}$ DIC. A detailed description of the PLFA-SIP calculations can be found in Boschker \& Middelburg (2002).

\section{Label transfer}

To determine the possible grazing on chemoautotrophic bacteria, we measured the ${ }^{13} \mathrm{C}$-labeling of the polychaetes recovered from the aquaria. Polychaetes were collected at the end of the incubation period, weighed, frozen and then lyophilized. Dried individuals were subsequently pulverized and analyzed by an elemental analyzer-isotope ratio mass spectrometer (EA-IRMS, Finnigan Delta S). Precision of the technique is of the order of $\pm 0.1 \% \delta^{13} \mathrm{C}$ for carbon isotopic values. The natural carbon isotopic composition was determined for 2 individuals of each species taken directly from the sampling site and analyzed as described in 'Experimental set-up'.

\section{Pore water analysis}

Pore water collected from flat aquaria at the end of the incubation was analyzed for DIC and total free
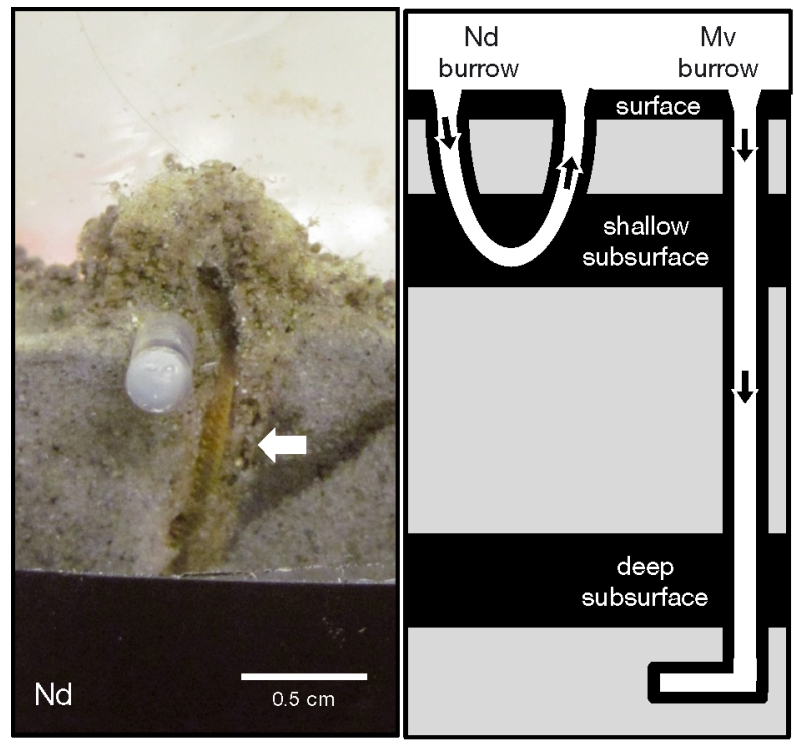

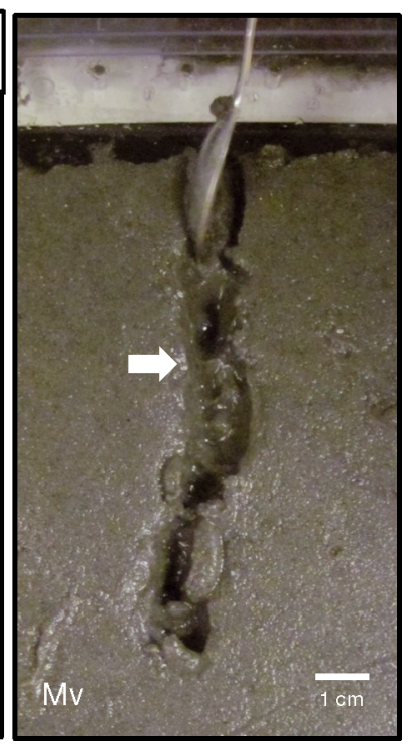

Fig. 1. Left: Nereis (Hediste) diversicolor $(\mathrm{Nd})$ and its burrow surrounded by an oxidized halo seen against the side of the flat aquarium. Right: sampled burrow area of Marenzelleria viridis (Mv). White arrows indicate the position of the burrow structure. Centre: schematic representation of the burrow geometry, burrow water flow (black arrows) and the 4 sediment zones sampled in black (burrow; surface 0 to $0.5 \mathrm{~cm}$; shallow subsurface 2 to $4 \mathrm{~cm}_{\text {; }}$ deep subsurface 12 to $14 \mathrm{~cm}$ ) 
sulfide $\left(\Sigma \mathrm{H}_{2} \mathrm{~S}=\left[\mathrm{H}_{2} \mathrm{~S}\right]+\left[\mathrm{HS}^{-}\right]+\left[\mathrm{S}^{2-}\right]\right)$. DIC samples $(0.5 \mathrm{ml})$ were collected in gas-tight vials and preserved with $30 \mu \mathrm{l}$ of a saturated $\mathrm{HgCl}_{2}$ solution. Total DIC and $\delta^{13} \mathrm{C}$ DIC were measured by the headspace technique using an EA-IRMS equipped with a gas injection port (Boschker et al. 2014). Background carbon isotopic values were analyzed on pore water in parallel samples from the 2 Control aquaria without ${ }^{13} \mathrm{C}$ substrate addition. $\Sigma \mathrm{H}_{2} \mathrm{~S}$ samples $(0.5 \mathrm{ml})$ were fixed with $50 \mu \mathrm{l}$ of a $1 \mathrm{M}$ zinc acetate solution and analyzed following Cline (1969) (precision of $\pm 2 \%$ and sensitivity at $\mathrm{pH} 0.35$ of $29.5 \times 10^{3} \mathrm{l} \mathrm{mol}^{-1} \mathrm{~cm}^{-1}$ ). Weight loss of wet sediment subsamples after drying at $60^{\circ} \mathrm{C}$ for $48 \mathrm{~h}$ was used for porosity determination.

\section{Statistical analysis}

All statistical analyses were performed using the extension package CRAN: stats in the open-source software R. Normal distribution (Shapiro-Wilks test) and homogeneity of variance (Barlett's test) were tested for each data set, and data were log-transformed when necessary to fulfill the assumptions of ANOVA. A 2-way ANOVA was used to test the effect of polychaete treatments and sediment depths on bacterial biomass and chemoautotrophic activity. Depth-integrated pore water DIC and $\Sigma \mathrm{H}_{2} \mathrm{~S}$ were tested with 1-way ANOVA for treatment effects. Significant differences were further analyzed using a Tukey's multiple comparisons of means (Tukey's HSD). Both PLFA concentrations and ${ }^{13} \mathrm{C}$ incorporation values were expressed as a fraction of the total per sediment sample. Relative PLFA values were logtransformed as $[\log (x+1)]$ and analyzed with principal component analysis (PCA) to determine differences in the microbial assemblage and within the chemoautotrophic community among layers and treatments. Only PLFAs contributing more than $0.1 \%$ to the total sediment activity were included in the PCA analysis.

\section{RESULTS}

\section{Sediment appearance}

The surface sediment in all treatments had a similar appearance after $6 \mathrm{~d}$ of acclimatization, and consisted of a light brown surface sediment layer indicative of oxidized conditions, while the sediment below showed a dark grey coloration suggesting reduced conditions. The oxidized surface layer was $\sim 4 \mathrm{~mm}$ deep in the Control, 3 to $4 \mathrm{~mm}$ in $\mathrm{Nd}$ and only $\sim 1.5 \mathrm{~mm}$ in the Mv sediments. However, on closer inspection, $\mathrm{Nd}$ and $\mathrm{Mv}$ sediments exhibited several physical differences. The surface sediment in $\mathrm{Nd}$ aquaria was loose and fluffy (indicating surface reworking) and detritus accumulations were present around burrow openings, whereas surface sediment in Mv aquaria appeared more compact (Fig. 1). Sediment surrounding the burrow in the $\mathrm{Nd}$ aquaria had a brownish coloration similar to the oxidized surface layer (Fig. 1). Nd burrows were typically U-shaped and reached between 2 and $4 \mathrm{~cm}$ into the sediment. One aquarium contained 1 burrow, whereas the other 2 aquaria had several burrows; however, only the active and inhabited burrow was sampled for analysis. Each Mv aquarium had only 1 burrow, which was straight, penetrating up to $18 \mathrm{~cm}$ deep, and had a similar grey coloration to the subsurface sediment (Fig. 1). One of the $3 \mathrm{Mv}$ aquaria was discarded because the worm was found outside the aquarium at the end of the incubation. The burrows of Nereis (Hediste) diversicolor and Marenzelleria viridis both had an average burrow diameter of $3 \mathrm{~mm}$.

The porosity ranged from 0.31 to 0.47 between treatments and depths, with an overall mean depthintegrated value of $0.39 \pm 0.05$, which was in agreement with previous analyses of the same sediment (Quintana et al. 2007, Jovanovic et al. 2014).

\section{Total bacterial community}

Surface, burrow and 2 subsurface depths (shallow and deep) were examined using PLFA analysis. A total of 39 PLFAs were identified, of which 29 were considered as bacterial biomarkers. The PLFAs not used in our data analysis were polyunsaturated fatty acids (PUFAs), which are considered to be eukaryote biomarkers (Vestal \& White 1989). These PUFAs were mostly present in the surface samples and accounted for $6 \%$ of the total PLFAs. A subset of 14 out of 29 bacterial fatty acids represented more than $90 \%$ of the total bacterial biomass per sample (Fig. 2). Major bacterial PLFAs were 16:107c (25 \pm $0.3 \%), 18: 1 \omega 7 \mathrm{c}(22 \pm 0.9 \%), 16: 0(19 \pm 0.6 \%), 18: 1 \omega 9 \mathrm{c}$ $(5 \pm 0.2 \%), 14: 0(5 \pm 0.3 \%)$, ai15:0 $(4 \pm 0.3 \%), 16: 1 \omega 7 \mathrm{t}$ $(2 \pm 0.9 \%)$, i15:0 $(2 \pm 0.1 \%)$ and 18:0 $(2 \pm 0.1 \%)$, whereas minor fatty acids ( 1 to $2 \%$ ) included 15:0, 16:1 $\omega 5,17: 1 \omega 8 \mathrm{c}, 17: 1 \omega 6 \mathrm{c}$ and 17:0.

The 2-way ANOVA (Shapiro-Wilks p $=0.39$; Bartlett $p=0.56$ ) on log-transformed bacterial biomass data showed a statistically significant effect of sediment depth $\left(F_{3,24}=10.95, \mathrm{p}=0.0001\right)$ rather than 
A

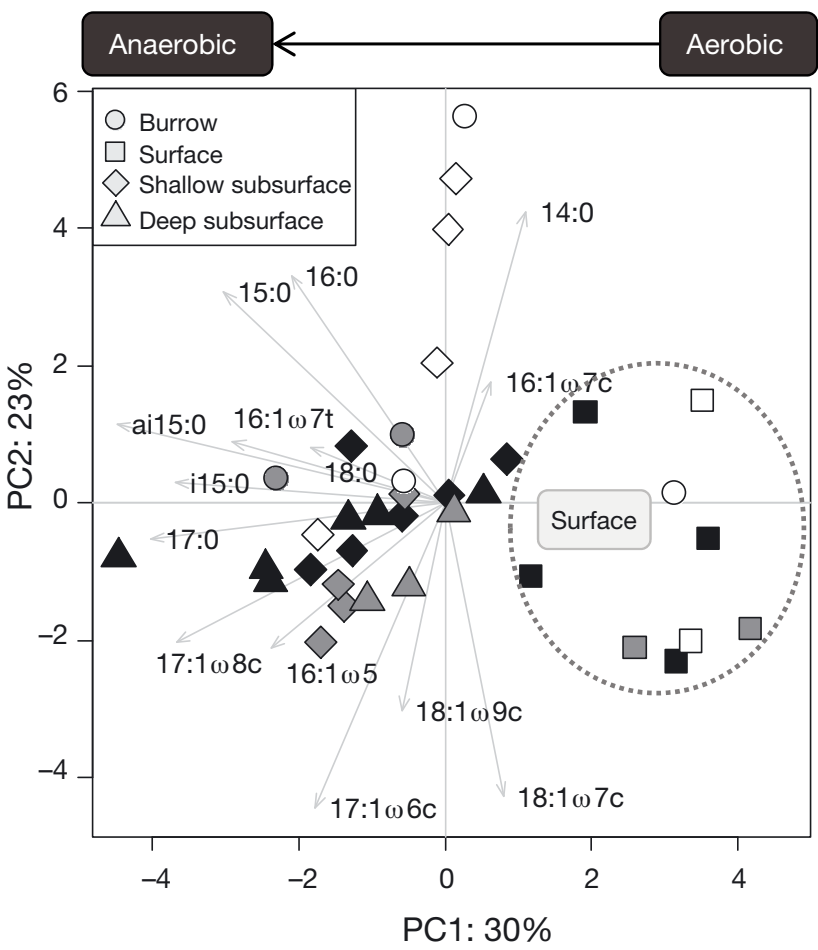

B

PLFA ${ }^{13} \mathrm{C}$-incorporation

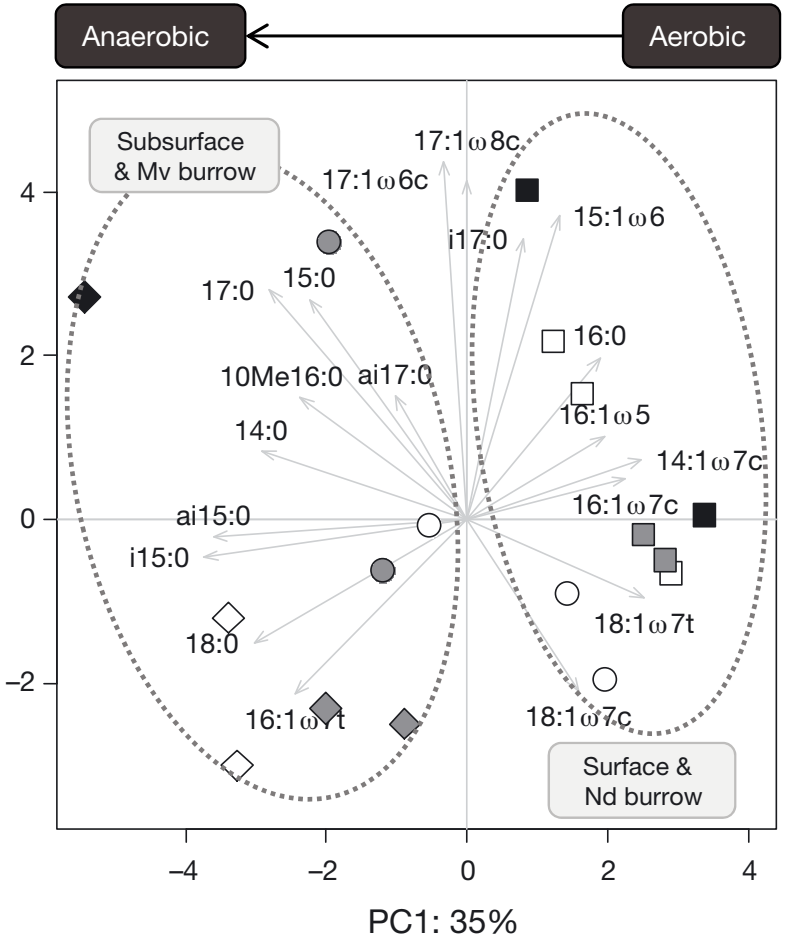

Fig. 2. PCA of (A) PLFA concentrations (nmol C-PLFA $[g \text { dry } w t]^{-1}$ ) and (B) ${ }^{13} \mathrm{C}$ incorporation (pmol $\left.{ }^{13} \mathrm{C}[\mathrm{g} d r y \mathrm{wt}]\right]^{-1}$ ) for each sediment depth. Values were log-transformed prior to analysis. The percent of variation amongst samples explained by each of the first 2 principal components (PC) is given on the corresponding axis. Grey arrows represent the proportion of total variance explained by each PLFA. Black: Control (without bioturbation); white: Nereis (Hediste) diversicolor (Nd); grey: Marenzelleria viridis $(\mathrm{Mv})$. Sediment depths are represented by different symbols as noted in legend (burrow; surface 0 to $0.5 \mathrm{~cm}$; shallow subsurface 2 to $4 \mathrm{~cm}$; deep subsurface 12 to $14 \mathrm{~cm}$ )

treatment $\left(F_{2,24}=00.189, \mathrm{p}=0.83\right)$. Tukey's HSD showed that differences occurred mainly between the higher bacterial abundance in surface sediments compared to the lower values in both subsurface sediments (shallow subsurface $p=0.0009$, deep subsurface $p=0.00009$ ). In general, subsurface bacterial biomass represented 55 to $65 \%$ of the surface biomass (Table 1). The 1-way ANOVA for the bacterial biomass in the Control showed statistical differences between layers $\left(F_{2,11}=4.421, \mathrm{p}=0.039\right)$, with the bac- terial biomass in surface sediment not significantly different from that in the shallow subsurface (Tukey's HSD $p=0.52$ ) but significantly higher than in the deep subsurface (Tukey's HSD $p=0.05$ ). In the Nd treatment, 1-way ANOVA $\left(F_{2,6}=6.961, \mathrm{p}=0.027\right)$ showed that the bacterial biomass in the burrow was not statistically different from that in the surface sediment (Tukey's HSD p = 0.53), whereas for the Mv treatment 1-way ANOVA $\left(F_{3,7}=7.923, \mathrm{p}=0.012\right)$, the bacterial biomass in the burrow was lower than that

Table 1. Bacterial biomass and chemoautotrophy rates (mean \pm SD) for the different treatments and sediment depths studied. Number of replicates is stated in parentheses next to the treatment code. Control: no bioturbation; Nd: Nereis (Hediste) diversicolor; Mv: Marenzelleria viridis; na: not applicable; nd: not detected; surface: 0 to $0.5 \mathrm{~cm}$; shallow subsurface: 2 to $4 \mathrm{~cm}$; deep subsurface: 12 to $14 \mathrm{~cm}$. Ranges are stated when there were only 2 replicates

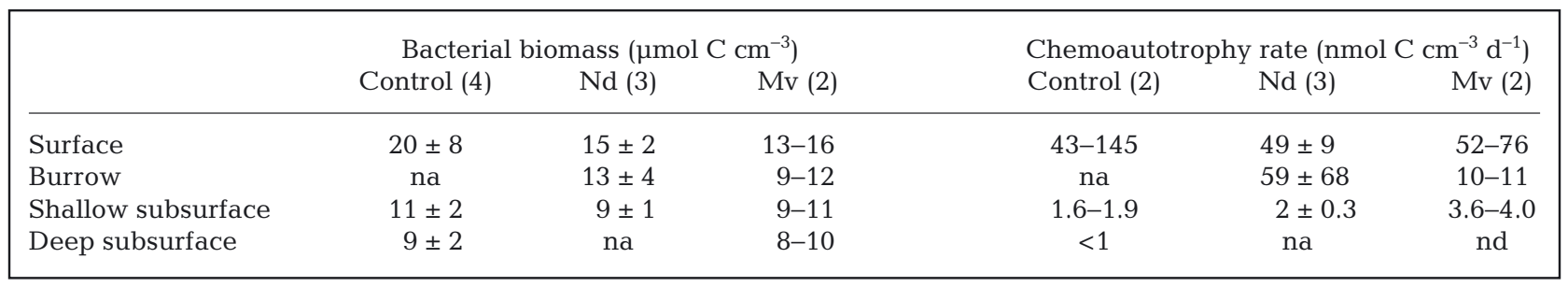


in the surface (Tukey's HSD p $=0.07$ ), but not statistically different from subsurface biomass (Tukey's HSD $\mathrm{p}>0.6$ ).

The bacterial community composition characterized through PLFA fingerprinting showed differences between depth layers along the first principal component axis, with a total of $53 \%$ of the variation between samples explained by the first 2 principal components (Fig. 2A). Surface samples for all treatments showed a clear differentiation from deeper layers, with a higher contribution of $16: 1 \omega 7 \mathrm{C}$, $18: 1 \omega 7 \mathrm{c} / 9 \mathrm{c}$ and $14: 0$. Of the $3 \mathrm{Nd}$ burrow samples, 2 also clustered with the surface samples, whereas $\mathrm{Mv}$ burrows resembled PLFA patterns of the subsurface. Deeper sediments increased by $\sim 15 \%$ in the relative contribution of ai15:0 compared to surface samples, and 16:1 $\omega 7 \mathrm{t}$ was only present in deeper layers.

\section{Chemoautotrophic community}

Combining the PLFA fingerprint technique with SIP allows for a targeted study of the active chemoautotrophic bacterial community. The incorporation of ${ }^{13} \mathrm{C}$-label was determined for 20 bacterial fatty acids. The following 3 PLFAs consistently displayed the highest ${ }^{13} \mathrm{C}$ assimilation: $16: 1 \omega 7 \mathrm{C}(34 \pm 4 \%)$, $18: 1 \omega 7 \mathrm{C}(26 \pm 5 \%)$ and 16:0 (17 $\pm 2 \%)$. However, PCA showed a clear divergence in the composition of the chemoautotrophic bacterial community between surface and subsurface samples (Fig. 2B). Surface samples were characterized by more label uptake into even-numbered mono-unsaturated fatty acids, while synthesis of branched and saturated fatty acids prevailed in subsurface samples. Burrow sediments exhibited a specific PLFA fingerprint for each polychaete treatment (Fig. 2B). Nd burrow samples showed the highest relative ${ }^{13} \mathrm{C}$ incorporation into $16: 1 \omega 7 \mathrm{C}(36 \pm 2 \%)$ and $18: 1 \omega 7 \mathrm{C}(30 \pm 5 \%)$, which was similar to that observed for surface samples. Nonetheless, 1 replicate $\mathrm{Nd}$ burrow had less $18: 1 \omega 7 \mathrm{C}$ $(25 \%)$ and thus clustered towards the subsurface PLFA fingerprint in the PCA (Fig. 2B). Mv burrows showed at least 3 times higher ${ }^{13} \mathrm{C}$ incorporation into ai15:0 (8\%) and i15:0 (2.5\%) than surface sediments, therefore closely resembling subsurface PLFA patterns. Moreover, mono-unsaturated fatty acid 16:1 $17 \mathrm{t}$ was prevalent in subsurface sediment but differed between treatments, with an average incorporation of $10 \%$ for $\mathrm{Nd}$ and $4 \%$ for $\mathrm{Mv}$ and the Control treatment.

Overall, the highest chemoautotrophy rates were found in the surface and the lowest in the subsurface sediments (Table 1). Very low chemoautotrophic activities were detected within the deep subsurface layer of all treatments (12 to $14 \mathrm{~cm}$ deep) and, therefore, these data were not considered for further analysis. The 2-way ANOVA (Shapiro-Wilks $\mathrm{p}=$ 0.053 ; Bartlett $\mathrm{p}=0.55$ ) performed on log-transformed (volumetric) chemoautotrophy rates showed significant differences between all sediment zones $\left(F_{2,11}=47.432, \mathrm{p}=3.9 \times 10^{-6}\right)$. However, Nd burrow and surface rates were the only pair that were not significantly different (Tukey's HSD $p=0.857$ ) and both were on average 20 times higher than subsurface rates. In contrast, the mean dark $\mathrm{CO}_{2}$ fixation rate of $\mathrm{Mv}$ burrows was only $15 \%$ of the surface rate and 2.5 times higher than subsurface activity. Subsurface chemoautotrophic activity was 2-fold higher in $\mathrm{Nd}$ and 4 -fold higher in $\mathrm{Mv}$ when compared to the subsurface activity in the Control treatment.

\section{Trophic interactions}

Isotope results from field-collected specimens revealed a natural $\delta^{13} \mathrm{C}$ signal of -15 to $-14 \%$ for $N$. diversicolor and -14 to $-13 \%$ for $M$. viridis. All polychaetes retrieved from ${ }^{13} \mathrm{C}$-labeled incubations were alive and motile at the end of the incubation period, and were used to determine possible ${ }^{13} \mathrm{C}$ enrichment. All polychaetes were enriched in ${ }^{13} \mathrm{C}$, and $\delta^{13} \mathrm{C}$ values were more pronounced for $M$. viridis $(-1$ to $-2 \%)$ than for $N$. diversicolor $(-11$ to $-7 \%)$, suggesting a higher grazing of chemoautotrophic bacteria by $M$. viridis than by $N$. diversicolor.

\section{Pore water chemistry}

Free sulfide $\left(\Sigma \mathrm{H}_{2} \mathrm{~S}\right)$ concentrations in the pore water of the Control and $\mathrm{Nd}$ treatment were low at the surface ( 0.1 mM), increasing to $2.5 \mathrm{mM}$ at $5 \mathrm{~cm}$ depth, and remaining fairly constant deeper down (Fig. 3A). The increase in $\Sigma \mathrm{H}_{2} \mathrm{~S}$ for $\mathrm{Mv}$ was less pronounced, only reaching $1 \mathrm{mM}$ at $5 \mathrm{~cm}$ depth and then gradually increasing to $3 \mathrm{mM}$ at $17 \mathrm{~cm}$ depth. However, 1-way ANOVA (Shapiro-Wilks $\mathrm{p}=0.74$; Bartlett $\mathrm{p}=0.94)$ showed that the pore water $\Sigma \mathrm{H}_{2} \mathrm{~S}$ inventories (depth-integrated $\Sigma \mathrm{H}_{2} \mathrm{~S}$ up to $20 \mathrm{~cm}$ ) were not statistically different $\left(F_{2,6}=0.592, \mathrm{p}=0.582\right)$ between treatments (Nd: $82 \pm 38$; Mv: 29 to 69; Control: $73 \pm$ $32 \mathrm{mmol} \mathrm{m}^{-2}$ ). DIC showed a pattern similar to that of $\Sigma \mathrm{H}_{2} \mathrm{~S}$, with a rapid increase in the Control and $\mathrm{Nd}$ treatment from overlying water values $(\sim 2 \mathrm{mM})$ at the sediment surface to $\sim 9 \mathrm{mM}$ at $5 \mathrm{~cm}$ depth 

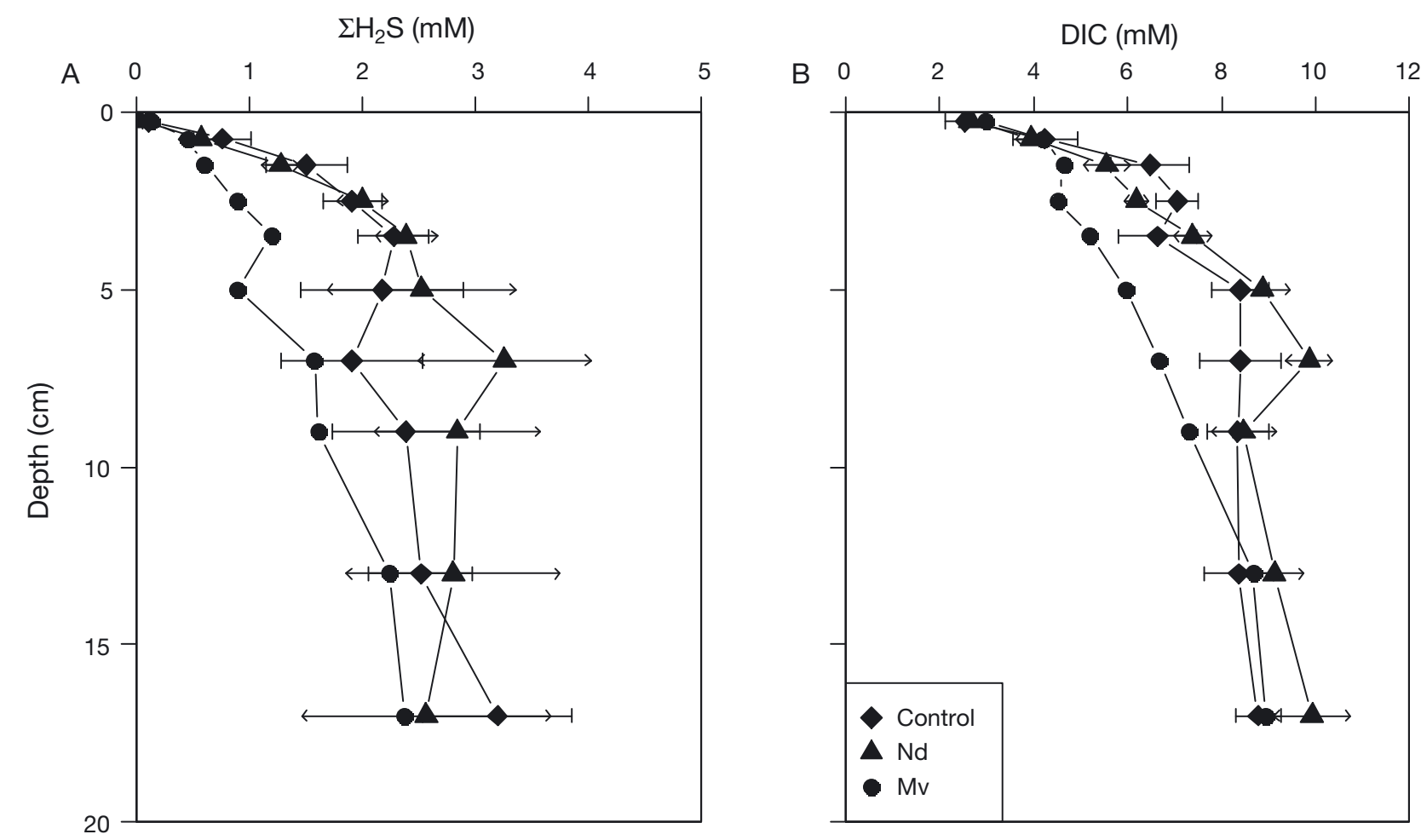

Fig. 3. Sediment pore water profiles for (A) $\Sigma \mathrm{H}_{2} \mathrm{~S}$ and (B) dissolved inorganic carbon (DIC) for the different treatments (Control: no bioturbation; Nd: Nereis (Hediste) diversicolor; Mv: Marenzelleria viridis). Error bars show SE (Control: $\mathrm{n}=4 ; \mathrm{Nd}: \mathrm{n}=3$; $\mathrm{Mv}: \mathrm{n}=2$ )

(Fig. 3B). The 1-way ANOVA (Shapiro-Wilks $\mathrm{p}=$ 0.65 ; Bartlett $\mathrm{p}=0.19$ ) showed that depth-integrated DIC was statistically different between treatments $\left(F_{2,6}=6.839, \mathrm{p}=0.028\right)$, with a DIC inventory of 223 to $224 \mathrm{mmol} \mathrm{m}^{-2}$ for $\mathrm{Mv}, 276 \pm 15 \mathrm{mmol} \mathrm{m}^{-2}$ for $\mathrm{Nd}$ and $260 \pm 19 \mathrm{mmol} \mathrm{m}^{-2}$ for the Control treatment. The Mv treatment showed a more gradual increase in DIC, which was significantly different from $\mathrm{Nd}$ (Tukey's HSD $p=0.02$ ) and to a lesser degree from Control (Tukey's HSD p $=0.08$ ).

\section{DISCUSSION}

\section{Bacterial community}

Sediment bioturbated by Nereis (Hediste) diversicolor and Nereis virens has shown 4 to 5 times higher bacterial abundance at the surface and burrow when compared to subsurface sediment (Papaspyrou et al. 2006). Likewise, Dobbs \& Guckert (1988) observed an enrichment of bacterial biomass associated with the burrow lining of deep-burrowing shrimp Callianassa trilobata, while sediment from the burrow wall had a similar bacterial biomass to that of subsurface sediment. PLFA analysis of sediment biotur- bated by 3 polychaete species (Notomastus lobatus, Branchyoasychus americana and Balanoglossus aurantiacus) has shown a 20 to $75 \%$ species-dependent decrease in bacterial biomass from the surface to the burrow (Steward et al. 1996). Our Mv and Nd treatments followed a similar trend, with $\sim 36 \%$ higher bacterial biomass in the surface sediment than in the subsurface, while bacterial biomass in $\mathrm{Mv}$ and Nd burrows was only 13 and $26 \%$, respectively, lower than surface bacterial abundances.

The biomarker patterns revealed distinct differences in microbial communities between surface and subsurface sediments. Furthermore, PLFA patterns in burrow and surface sediment were alike for $\mathrm{Nd}$, whereas in the Mv treatment, the biomarker fingerprint of the burrow resembled that of the subsurface sediment. Nd burrow and surface sediment contained higher quantities of $16: 1 \omega 7 \mathrm{c}$ and $18: 1 \omega 7 \mathrm{c}$, and although these compounds are ubiquitous amongst bacteria, they are typically more abundant in aerobic environments (Vestal \& White 1989). The dominance of an aerobic microbial community in the Nd burrow is in line with our observation of oxidized conditions (light brown halo around the burrow lining) and the intense ventilation (i.e. pumping of burrow with oxygenated waters) known to be performed by $N$. diversi- 
color (Pischedda et al. 2012). In contrast, the burrow of Marenzelleria viridis and subsurface sediments showed increased concentrations of ai15:0 and i15:0, which are compounds that indicate a high proportion of anaerobic metabolism (Findlay et al. 1990, Bühring et al. 2005). The enhancement of anaerobic activity in burrow sediments of $M$. viridis rather than $N$. diversicolor is consistent with the known impact of $M$. viridis bioturbation on sediment geochemistry, which boosts anaerobic processes such as sulfate reduction (Kristensen et al. 2011, Quintana et al. 2013).

A decrease in the concentration of $16: 1 \omega 7 \mathrm{C}$ combined with an increase in its trans form $(16: 1 \omega 7 \mathrm{t})$ observed in the subsurface of all treatments may be linked to ambient stress on the bacteria (Findlay et al. 1989, Vestal \& White 1989). Nevertheless, sieving compared to freezing or asphyxiation has been found to be the least disruptive method in regard to the magnitude of the effect and recovery time, both of the microbial community and the geochemical conditions (Porter et al. 2006, Stocum \& Plante 2006). Manipulated sediments can, however, take between $5 \mathrm{~d}$ and $2 \mathrm{wk}$ to reach a steady state or resemble natural biogeochemical conditions (Findlay et al. 1990, Kristensen 2001, Porter et al. 2006, Stocum \& Plante 2006), which suggests that after a short acclimatization period, opportunistic, fast-growing bacteria may be favored in sediments. It is possible that the weeklong acclimatization of the microbial community in our incubations may not have allowed for the complete recovery of the slow-growing microbial community after the initial disturbance of the sediment (i.e. sieving and homogenization). However, chemoautotrophic bacteria, generally exhibiting slow growth, have been shown to develop rapidly ( $1 \mathrm{wk})$ in homogenized cohesive, sulfide-rich sediments (Vasquez-Cardenas et al. 2015). Hence, both the sediment manipulation technique and the incubation time may strongly determine the microbial community in the sediment and should be considered during the experimental design phase in similar studies.

\section{Chemoautotrophic community}

PLFA-SIP analysis showed that the chemoautotrophic bacteria associated with the $\mathrm{Nd}$ burrow sediment grouped with those of surface sediments, whereas chemoautotrophs from the Mv burrow clustered with those of subsurface samples. Prevalence of aerobic or anaerobic bacterial communities in burrow environments has previously been linked to the functional traits of the macrofauna (Dobbs \& Guckert
1988, Steward et al. 1996, Papaspyrou et al. 2006, Laverock et al. 2010, Gilbertson et al. 2012), and our results confirm this species-specific bioturbation effect.

$N$. diversicolor intermittently ventilates its U-shaped burrow in regular cycles of $\sim 10$ min ventilation and $\sim 5$ min resting periods (Pischedda et al. 2012). The final result is a strong oxygenation of the burrow, with a mean oxygen concentration of $\sim 70 \%$ saturation in the burrow. The $\mathrm{O}_{2}$ concentration in the inhalant opening matches that of the overlying water and decreases towards the exhalant opening, with the lowest $\mathrm{O}_{2}$ values being encountered at the bottom of the burrow (Pischedda et al. 2012). From the oxygenated burrow, oxygen diffuses into the sediment, sustaining oxidized conditions (over 0.5 to $3 \mathrm{~mm}$ ) and generating steep chemical gradients radially from the center of the burrow towards the surrounding sediment. This radial transport of oxygen stimulates the aerobic re-oxidation of reduced compounds by bacteria within the burrow (Banta et al. 1999). Strong aerobic activity is also inferred from the high chemoautotrophic labeling of even-numbered mono-unsaturated 16- and 18-carbon fatty acids in the $\mathrm{Nd}$ burrow sediment, similar to the aerobic PLFA pattern noted in the surface sediment of all treatments. These mono-unsaturated PLFAs are also highly abundant in sulfur-, nitriteand ammonium-oxidizing chemoautotrophic bacteria (Blumer et al. 1969, Lipski et al. 2001, Knief et al. 2003, Inagaki et al. 2004, Labrenz et al. 2013, Boschker et al. 2014). The nitrification potential of Nereis spp. burrows substantially exceeds that of surface sediments (Kristensen \& Kostka 2005); yet, here chemoautotrophy rates in the burrow and surface sediment of the Nd treatment were similar. Nitrifying bacteria have generally lower growth yields than sulfur-oxidizing bacteria (Boschker et al. 2014) and thus their activity may be underrepresented by the PLFA-SIP technique. Nonetheless, biomarker analysis of $\mathrm{Nd}$ burrows and surface sediments points to an aerobic chemoautotrophic community composed of sulfur-oxidizing and nitrifying bacteria.

Chemoautotrophy rates in $\mathrm{Nd}$ burrows were variable, with 1 replicate exceeding the other 2 by more than $80 \%$, possibly due to the distinct burrowing behavior in the replicate aquaria. Several burrow openings were observed in the aquaria with the lowest chemoautotrophy rates, while only 1 burrow was found in the most active aquarium. In the aquaria with more than 1 burrow, Nd individuals apparently rebuilt and changed burrow over the course of the experiment. PCA analysis further showed that the less active Nd burrow had a larger contribution of anaero- 
bic bacterial biomarkers (ai15:0 and i15:0), suggesting that the burrow was occupied only shortly before sampling. In fact, the residence time of burrows is an important factor determining the succession and maturation of the microbial community (Marinelli et al. 2002). Therefore, the higher aerobic chemoautotrophy found in the aquarium with $1 \mathrm{Nd}$ burrow suggests that stable burrows with steady ventilation strongly affect the chemoautotrophic bacterial community.

The effects of burrowing by $M$. viridis on the geochemistry and microbial community are opposite to those of $N$. diversicolor. $M$. viridis ventilates its blindended burrow 10 times less than $N$. diversicolor, which results in $75 \%$ air saturation at the burrow opening, which quickly decreases with depth along the burrow axis until anoxic conditions are obtained, interrupted by sporadic bursts of faint oxygenation ( $8 \%$ air saturation) at the burrow end (Quintana et al. 2011, Jovanovic et al. 2014). Nonetheless, M. viridis has a stronger irrigation capacity due to deep burrowing and the percolation of return water through the sediment, which tends to dilute the pore water chemistry, as seen in the DIC and $\Sigma \mathrm{H}_{2} \mathrm{~S}$ depth profiles over the top $10 \mathrm{~cm}$ (Fig. 3). Pore water is injected from the burrow into the surrounding sediment and is pushed upwards to the sediment-water interface through advective transport, which increases the efflux of pore water solutes (Quintana et al. 2007, Jovanovic et al. 2014). This transport induced by $M$. viridis translates into a 10 -fold increase of the chemoautotrophic activity in the burrow compared with the Control subsurface sediment, but the chemoautotrophic activity still remains lower than that in the sediment surface. In agreement with the overall anaerobic conditions in the Mv burrow, the burrow sediment was characterized by biomarkers typical for sulfate reduction, such as i15:0, ai15:0, i17:1, 10Me16:0, 17:1 and 16:1 (Taylor \& Parkes 1983, Edlund et al. 1985, Boschker \& Middelburg 2002, Webster et al. 2006). A chemoautotrophy study by Miyatake (2011) found similar PLFA-SIP patterns to those in our Mv sediment, which were attributed to sulfate-reducing bacteria from the Deltaproteobacteria performing sulfur disproportionation. The enhanced chemoautotrophic anaerobic activity in the presence of $M$. viridis was, therefore, attributed to such Deltaproteobacteria.

\section{Chemoautotrophy rates}

A long-held notion is that burrows are interfaces between oxic and anoxic sediments, and serve as hot spots of re-oxidation processes and hence of chemoautotrophic activity (Aller 1988, Kristensen \& Kostka 2005). Apart from our study, only Reichardt (1988) directly quantified chemoautotrophic carbon fixation in the burrow of the lugworm Arenicola marina ( $\left.500 \mathrm{nmol} \mathrm{C} \mathrm{cm}{ }^{-3} \mathrm{~d}^{-1}\right)$. These chemoautotrophy rates are 8 times higher than the rates from Nd burrows and 48 times higher than the Mv treatment of our study. A. marina is a strong bioturbator, both in regards to particle reworking and burrow ventilation (Meysman et al. 2005), thus higher re-oxidation rates would be expected in burrows of lugworms rather than in Mv and Nd burrows (Fig. 4).

Aerobic chemoautotrophy rates obtained in our study (40 to $145 \mathrm{nmol} \mathrm{C} \mathrm{cm}{ }^{-3} \mathrm{~d}^{-1}$ ) are in the lower range reported for coastal sediments characterized by non-mat-forming sulfur oxidizers (100 to $200 \mathrm{nmol}$ $\mathrm{C} \mathrm{cm}^{-3} \mathrm{~d}^{-1}$ from 0 to $2 \mathrm{~cm}$ deep; Thomsen \& Kristensen 1997, Lenk et al. 2011, Boschker et al. 2014). In organic-poor, permeable sediments, $\sim 70 \%$ of the total dark $\mathrm{CO}_{2}$ fixation can be attributed to sulfuroxidizing Gammaproteobacteria not related to filamentous morphotypes (Lenk et al. 2011). However, much higher in situ chemoautotrophy rates (900 to $7000 \mathrm{nmol} \mathrm{C} \mathrm{cm}{ }^{-3} \mathrm{~d}^{-1}$ ) have been found in surface sediments colonized by white mats of filamentous sulfur oxidizers (Boschker et al. 2014). White bacterial mats have been observed at Mv burrow openings in several studies (Kristensen et al. 2011, Quintana et al. 2013, Renz \& Forster 2014), and white patches appeared on the surface of some of our incubations (Fig. 4). It is plausible that the upward flow of sulfideand ammonium-rich pore water to the sedimentwater interface, induced by the advective mode of pore water irrigation by $M$. viridis, favors the development of these microbial mats of filamentous sulfur oxidizers at the surface.

Alternatively, sulfate reducers within the Deltaproteobacteria, capable of sulfur disproportionation or $\mathrm{H}_{2}$ oxidation, have been proposed as key players of anaerobic chemoautotrophy in subsurface sediments (Thomsen \& Kristensen 1997, Miyatake 2011, Boschker et al. 2014). Anaerobic dark carbon fixation (10 to $40 \mathrm{nmol} \mathrm{C} \mathrm{cm}{ }^{-3} \mathrm{~d}^{-1}$ ) is usually lower than aerobic chemoautotrophy, as seen in intact sediments with limited bioturbation (Enoksson \& Samuelsson 1987, Lenk et al. 2011, Boschker et al. 2014) and in laboratory incubations with sieved sediment (Thomsen \& Kristensen 1997, Vasquez-Cardenas et al. 2015). Higher chemoautotrophic activity in the subsurface than in surface sediment has been observed in heavily bioturbated sediment by the lugworm A. marina (Reichardt 1988), plausibly as a result of 


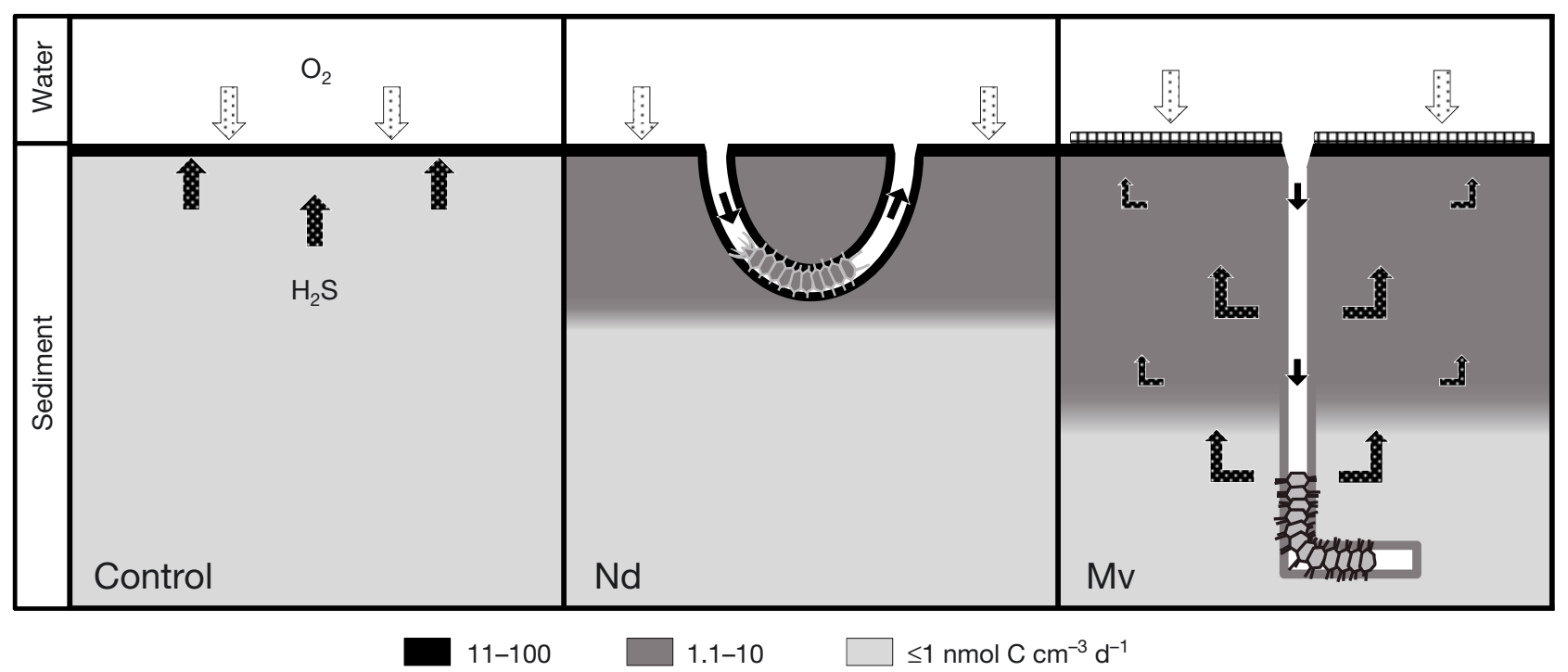

Fig. 4. A conceptual scheme summarizing the distribution of chemoautotrophic activity in the 3 treatments: Control (no bioturbation), Nereis (Hediste) diversicolor (Nd) and Marenzelleria viridis (Mv). Shading shows 3 ranges of chemoautotrophic activity. Black arrows in the sediment represent the direction of $\Sigma \mathrm{H}_{2} \mathrm{~S}$ flux and white arrows in the overlying water indicate $\mathrm{O}_{2}$ flux in the Control sediment. Burrows are U-shaped for $N$. diversicolor and L-shaped for $M$. viridis. Polychaetes are represented at the bottom of each burrow. Solid black arrows in burrows indicate the direction of pore water flow. Meshed areas at the burrow opening of $M$. viridis denote sulfur-oxidizing bacterial mat formations

the intense injection of oxic overlying water into the subsurface sediment (Meysman et al. 2005). However, we found limited chemoautotrophic activity in subsurface sediments ( 1 to $4 \mathrm{nmol} \mathrm{C} \mathrm{cm}^{-3} \mathrm{~d}^{-1}$ ), which accounted for less than $1 \%$ of the surface activity in non-bioturbated Controls and $\sim 5 \%$ in bioturbated sediments. $N$. diversicolor and $M$. viridis bioirrigate to a much lesser degree than $A$. marina (Kristensen et al. 2014) and thus only slightly stimulate subsurface chemoautotrophic activity compared to nonbioturbated subsurface sediments (Fig. 4).

\section{Trophic interaction}

Hylleberg (1975) first introduced the concept of bacterial gardening in lugworms, where bacterial biomass is enhanced for feeding purposes by the lugworms as a result of particle mixing, excretion of fecal pellet, breakdown of particles through grazing or transport of solutes by ventilation (Aller \& Yingst 1985). A study of the potential carbon sources of the head-down deposit feeder Heteromastus filiformis indicated a large dietary contribution by heterotrophic rather than chemoautotrophic bacteria (Clough \& Lopez 1993). Alternatively, an increased survival of the polychaete Capitella sp. 1 has been reported in organic-rich, sulfidic coastal sediments, which was linked to the ingestion of chemoautotrophic bacteria (Tsutsumi et al. 2001). Our stable isotope analysis also suggests that both $M$. viridis and $N$. diversicolor graze on chemoautotrophic bacteria in the sediment, given the observed ${ }^{13} \mathrm{C}$ enrichment. Comparison of excess ${ }^{13} \mathrm{C}$ fraction of the polychaetes with the corresponding chemoautotrophic activity showed that $M$. viridis can assimilate $0.017 \pm 0.003$ $\mathrm{d}^{-1}$ of the chemoautotrophic production, while $N$. diversicolor had a lower uptake rate of $0.010 \pm 0.002$ $\mathrm{d}^{-1}$. These results suggest a stronger grazing capacity of $M$. viridis on chemoautotrophic bacteria than $N$. diversicolor. Additionally, growth rates of $N$. diversicolor $\left(0.020\right.$ to $0.035 \mathrm{~d}^{-1}$; Kristensen 1984, Christensen et al. 2000) suggest that 30 to $50 \%$ of its diet could be supplemented by chemoautotrophs. However, $N$. diversicolor can switch from filter to deposit feeding when phytoplankton concentrations are low in overlying water (Christensen et al. 2000), therefore the high grazing of benthic chemoautotrophic bacteria observed in our incubations may be a consequence of depleted phytoplankton stocks in the water reservoir. Conversion of our uptake rates to biomass increment resulted in $2.8 \pm 0.9 \mathrm{mg} \mathrm{C}$ ind.$^{-1} \mathrm{~d}^{-1}$ for $M$. viridis and 6 times less for $N$. diversicolor $\left(0.5 \pm 0.1 \mathrm{mg} \mathrm{C}\right.$ ind. $\left.{ }^{-1} \mathrm{~d}^{-1}\right)$. $M$. viridis has been shown to have turnover rates twice as high as $N$. diversicolor, which is in agreement with the opportunistic behavior exhibited by Marenzelleria spp. (Sarda et al. 1995). 


\section{CONCLUSIONS}

In the absence of bioturbating fauna, chemoautotrophic activity and re-oxidation processes such as sulfur oxidation were primarily limited to the surface oxic-anoxic interface, given the depletion of oxidants in anoxic sediments (Fig. 4). In contrast, the 2 bioturbating polychaetes studied induced complex $\mathrm{O}_{2}$ and $\mathrm{H}_{2} \mathrm{~S}$ dynamics in the sediment, modulating the composition of the microbial community and the associated metabolic activity. Strong ventilation by Nereis (Hediste) diversicolor extended the oxic microenvironments into the sediment, where aerobic dark carbon fixation through sulfide oxidation and nitrification were mainly promoted along the burrow whereas the slower pumping behavior combined with deeper burrows of Marenzelleria viridis enhanced anaerobic microbial metabolism (i.e. sulfate reduction and sulfur disproportionation) in subsurface sediment. Concomitantly, the upward pumping of sulfidic and nutrientrich pore water by $M$. viridis may potentially promote the development of sulfur-oxidizing microbial mats on the surface, as seen in field observations (Kristensen et al. 2011, Quintana et al. 2013, Renz \& Forster 2014). More targeted food web studies are necessary to determine the potential gardening of these microbial mats by $M$. viridis. In conclusion, the spatial distribution and magnitude of microbial processes, such as chemoautotrophy, can be strongly regulated by the species-specific functional traits of macrofauna, and the extent of these effects should be examined in intact coastal sediments.

Acknowledgements. We gratefully acknowledge Zeljko Jovanovic for fieldwork assistance and support during the preparation of the experiments, Peter van Breugel and Marco Houtekamer for their assistance with the stable isotope analysis, Dick van Oevelen for his insight on trophic interactions, Francesc Montserrat for fruitful discussions on bioturbation and Lucas Stal for his comments on the manuscript. The work was financially supported by a grant from the Darwin Centre for Geoscience (to H.T.S.B. and F.J.R.M.), ERC Grant 306933 (F.J.R.M.) and Grant \#12-127012 from the Danish Council for Independent Research/Natural Sciences (E.K.).

\section{LITERATURE CITED}

Aller RC (1988) Benthic fauna and biogeochemical processes in marine sediments: the role of burrow structures. In: Blackburn T, Sørensen J (eds) Nitrogen cycling in coastal marine environments. John Wiley \& Sons, New York, NY, p 301-338

Aller C, Yingst JY (1985) Effects of the marine deposit-feeders Heteromastus filiformis (Polychaeta), Macoma balthica (Bivalvia), and Tellina texana (Bivalvia) on averaged sedimentary solute transport, reaction rates, and microbial distributions. J Mar Res 43:615-645

Banta GT, Holmer M, Jensen MH, Kristensen E (1999) Effects of two polychaete worms, Nereis diversicolor and Arenicola marina, on aerobic and anaerobic decomposition in a sandy marine sediment. Aquat Microb Ecol 19: 189-204

Bertics VJ, Ziebis W (2009) Biodiversity of benthic microbial communities in bioturbated coastal sediments is controlled by geochemical microniches. ISME J 3:1269-1285

Bertics VJ, Ziebis W (2010) Bioturbation and the role of microniches for sulfate reduction in coastal marine sediments. Environ Microbiol 12:3022-3034

Blumer M, Chase T, Watson SW (1969) Fatty acids in the lipids of marine and terrestrial nitrifying bacteria. J Bacteriol 99:366-370

Boschker HTS, Middelburg JJ (2002) Stable isotopes and biomarkers in microbial ecology. FEMS Microbiol Ecol 40:85-95

Boschker HTS, Nold SC, Wellsbury P, Bos D and others (1998) Direct linking of microbial populations to specific biogeochemcial processes by ${ }^{13} \mathrm{C}$-labeling of biomarkers. Nature 392:801-805

Boschker HTS, Vasquez-Cardenas D, Bolhuis H, MoerdijkPoortvliet TWC, Moodley L (2014) Chemoautotrophic carbon fixation rates and active bacterial communities in intertidal marine sediments. PLoS ONE 9:e101443

> Braeckman U, Provoost P, Gribsholt B, Van Gansbeke D and others (2010) Role of macrofauna functional traits and density in biogeochemical fluxes and bioturbation. Mar Ecol Prog Ser 399:173-186

Bühring SI, Elvert M, Witte U (2005) The microbial community structure of different permeable sandy sediments characterized by the investigation of bacterial fatty acids and fluorescence in situ hybridization. Environ Microbiol $7: 281-293$

- Christensen B, Vedel A, Kristensen E (2000) Carbon and nitrogen fluxes in sediment inhabited by suspensionfeeding (Nereis diversicolor) and non-suspension-feeding ( $N$. virens) polychaetes. Mar Ecol Prog Ser 192: 203-217

> Cline J (1969) Spectrophotometric determination of hydrogen sulfide in natural waters. Limnol Oceanogr 14: 454-458

> Clough LM, Lopez GR (1993) Potential carbon sources for the head-down deposit-feeding polychaete Heteromastus filiformis. J Mar Res 51:595-616

> Cuny P, Acquaviva M, Miralles G, Stora G, Grossi V, Gilbert $F$ (2007) Influence of bioturbation by the polychaete Nereis diversicolor on the structure of bacterial communities in oil contaminated coastal sediments. Mar Pollut Bull 54:452-459

> Delefosse M, Banta GT, Canal-Vergés P, Penha-Lopes G and others (2012) Macrobenthic community response to the Marenzelleria viridis (Polychaeta) invasion of a Danish estuary. Mar Ecol Prog Ser 461:83-94

> Dobbs FC, Guckert JB (1988) Callianassa trilobata (Crustacea: Thalassinidea) influences abundance of meiofauna and biomass, composition, and physiologic state of microbial communities within its burrow. Mar Ecol Prog Ser 45:69-79

Edlund A, Nichols PD, Roffey R, White DC (1985) Extractable and lipopolysaccharide fatty acid and hydroxy acid profiles from Desulfovibrio species. J Lipid Res 26: 982-988 
Enoksson V, Samuelsson MO (1987) Nitrification and dissimilatory ammonium production and their effects on nitrogen flux over the sediment-water interface in bioturbated coastal sediments. Mar Ecol Prog Ser 36:181-189

> Findlay RH, King GM, Watling L (1989) Efficacy of phospholipid analysis in determining microbial biomass in sediments. Appl Environ Microbiol 55:2888-2893

- Findlay RH, Trexler MB, Guckert JB, White DC (1990) Laboratory study of disturbance in marine sediments: response of a microbial community. Mar Ecol Prog Ser 62:121-133

Gilbertson WW, Solan M, Prosser JI (2012) Differential effects of microorganism-invertebrate interactions on benthic nitrogen cycling. FEMS Microbiol Ecol 82:11-22

> Guckert JB, Antworth CP, Nichols PD, White DC (1985) Phospholipid, ester-linked fatty-acid profiles as reproducible assays for changes in prokaryotic community structure of estuarine sediments. FEMS Microbiol Ecol 31:147-158

> Hylleberg J (1975) Selective feeding by Abarenicola pacifica with notes on Abarenicola vagabunda and a concept of gardening in lugworms. Ophelia 14:113-137

> Inagaki F, Takai K, Nealson KH, Horikoshi K (2004) Sulfurovum lithotrophicum gen. nov., sp. nov., a novel sulfuroxidizing chemolithoautotroph within the Epsilonproteobacteria isolated from Okinawa Trough hydrothermal sediments. Int J Syst Evol Microbiol 54:1477-1482

$>$ Jørgensen BB (1978) Comparison of methods for the quantification of bacterial sulfate reduction in coastal marinesediments: measurement with radiotracer techniques. Geomicrobiol J 1:11-27

> Jovanovic Z, Larsen M, Quintana CO, Kristensen E, Glud RN (2014) Oxygen dynamics and porewater transport in sediments inhabited by the invasive polychaete Marenzelleria viridis. Mar Ecol Prog Ser 504:181-192

Knief C, Altendorf K, Lipski A (2003) Linking autotrophic activity in environmental samples with specific bacterial taxa by detection of ${ }^{13} \mathrm{C}$-labeled fatty acids. Environ Microbiol 5:1155-1167

Kristensen E (1984) Life cycle, growth and production in estuarine populations of the polychaetes Nereis virens and $N$. diversicolor. Holarctic Ecol 7:249-256

Kristensen E (2001) Impact of polychaetes (Nereis spp. and Arenicola marina) on carbon biogeochemistry in coastal marine sediments. Geochem Trans 2:92-103

Kristensen E, Kostka JE (2005) Macrofaunal burrows and irrigation in marine sediment: microbiological and biogeochemical interactions. In: Kristensen E, Haese RR, Kostka JE (eds) Interactions between macro- and microorganisms in marine sediments. American Geophysical Union, Washington, DC, p 125-158

Kristensen E, Hansen T, Delefosse M, Banta GT, Quintana CO (2011) Contrasting effects of the polychaetes Marenzelleria viridis and Nereis diversicolor on benthic metabolism and solute transport in sandy coastal sediment. Mar Ecol Prog Ser 425:125-139

Kristensen E, Penha-Lopes G, Delefosse M, Valdemarsen T, Quintana CO, Banta GT (2012) What is bioturbation? The need for a precise definition for fauna in aquatic sciences. Mar Ecol Prog Ser 446:285-302

- Kristensen E, Delefosse M, Quintana CO, Flindt MR, Valdemarsen $\mathrm{T}$ (2014) Influence of benthic macrofauna community shifts on ecosystem functioning in shallow estuaries. Front Mar Sci 1:1-14

Kunihiro T, Takasu H, Miyazaki T, Uramoto Y and others
(2011) Increase in Alphaproteobacteria in association with a polychaete, Capitella sp. I, in the organically enriched sediment. ISME J 5:1818-1831

Labrenz M, Grote J, Mammitzsch K, Boschker HTS and others (2013) Sulfurimonas gotlandica sp. nov., a chemoautotrophic and psychrotolerant epsilonproteobacterium isolated from a pelagic redoxcline, and an emended description of the genus Sulfurimonas. Int J Syst Evol Microbiol 63:4141-4148

> Laverock B, Smith CJ, Tait K, Osborn AM, Widdicombe S, Gilbert JA (2010) Bioturbating shrimp alter the structure and diversity of bacterial communities in coastal marine sediments. ISME J 4:1531-1544

> Lenk S, Arnds J, Zerjatke K, Musat N, Amann R, Mußmann M (2011) Novel groups of Gammaproteobacteria catalyse sulfur oxidation and carbon fixation in a coastal, intertidal sediment. Environ Microbiol 13:758-774

> Lipski A, Spieck E, Makolla A, Altendorf K (2001) Fatty acid profiles of nitrite-oxidizing bacteria reflect their phylogenetic heterogeneity. Syst Appl Microbiol 24:377-384

Marinelli RL, Lovell CR, Wakeham SG, Ringelberg DB, White DC (2002) Experimental investigation of the control of bacterial community composition in macrofaunal burrows. Mar Ecol Prog Ser 235:1-13

> Mermillod-Blondin F (2011) The functional significance of bioturbation and biodeposition on biogeochemical processes at the water-sediment interface in freshwater and marine ecosystems. J N Am Benthol Soc 30:770-778

Meysman FJR, Galaktionov OS, Middelburg JJ (2005) Irrigation patterns in permeable sediments induced by burrow ventilation: a case study of Arenicola marina. Mar Ecol Prog Ser 303:195-212

> Meysman FJR, Middelburg JJ, Heip CHR (2006) Bioturbation: a fresh look at Darwin's last idea. Trends Ecol Evol 21:688-695

Middelburg JJ, Barranguet C, Boschker HTS, Herman PMJ, Moens T, Heip CHR (2000) The fate of intertidal microphytobenthos carbon: an in situ ${ }^{13} \mathrm{C}$-labeling study. Limnol Oceanogr 45:1224-1234

Miyatake T (2011) Linking microbial community structure to biogeochemical function in coastal marine sediments. $\mathrm{PhD}$ dissertation, University of Amsterdam

- Papaspyrou S, Gregersen T, Kristensen E, Christensen B, Cox RP (2006) Microbial reaction rates and bacterial communities in sediment surrounding burrows of two nereidid polychaetes (Nereis diversicolor and $N$. virens). Mar Biol 148:541-550

> Pischedda L, Militon C, Gilbert F, Cuny P (2011) Characterization of specificity of bacterial community structure within the burrow environment of the marine polychaete Hediste (Nereis) diversicolor. Res Microbiol 162: 1033-1042

> Pischedda L, Cuny P, Esteves JL, Poggiale JC, Gilbert F (2012) Spatial oxygen heterogeneity in a Hediste diversicolor irrigated burrow. Hydrobiologia 680:109-124

> Porter ET, Owens MS, Cornwell JC (2006) Effect of sediment manipulation on the biogeochemistry of experimental sediment systems. J Coast Res 226:1539-1551

Quintana CO, Tang M, Kristensen E (2007) Simultaneous study of particle reworking, irrigation transport and reaction rates in sediment bioturbated by the polychaetes Heteromastus and Marenzelleria. J Exp Mar Biol Ecol 352:392-406

Quintana CO, Hansen T, Delefosse M, Banta G, Kristensen E (2011) Burrow ventilation and associated pore water 
irrigation by the polychaete Marenzelleria viridis. J Exp Mar Biol Ecol 397:179-187

Quintana CO, Kristensen E, Valdemarsen T (2013) Impact of the invasive polychaete Marenzelleria viridis on the biogeochemistry of sandy marine sediments. Biogeochemistry 115:95-109

Reichardt W (1988) Impact of bioturbation by Arenicola marina on microbiological parameters in intertidal sediments. Mar Ecol Prog Ser 44:149-158

Renz JR, Forster S (2014) Effects of bioirrigation by the three sibling species of Marenzelleria spp. on solute fluxes and porewater nutrient profiles. Mar Ecol Prog Ser 505: 145-159

Sarda R, Valiela I, Foreman K (1995) Life cycle, demography, and production of Marenzelleria viridis in a salt marsh of southern New England. J Mar Biol Assoc UK 75: 725-738

Steward CC, Nold SC, Ringelberg DB, White DC, Lovell CR (1996) Microbial biomass and community structures in the burrows of bromophenol producing and non-producing marine worms and surrounding sediments. Mar Ecol Prog Ser 133:149-165

Stocum ET, Plante CJ (2006) The effect of artificial defaunation on bacterial assemblages of intertidal sediments. J Exp Mar Biol Ecol 337:147-158

Taylor J, Parkes RJ (1983) The cellular fatty acids of the

Editorial responsibility: Martin Solan,

Southampton, UK sulfate-reducing bacteria, Desulfobacter sp., Desulfobulbus sp. and Desulfovibrio desulfuricans. J Gen Microbiol 129:3303-3309

Thomsen U, Kristensen E (1997) Dynamics of sigmaCO $\mathrm{CO}_{2}$ in a surficial sandy marine sediment: the role of chemoautotrophy. Aquat Microb Ecol 12:165-176

Tsutsumi H, Wainright S, Montani S, Saga M, Ichihara S, Kogure K (2001) Exploitation of a chemosynthetic food resource by the polychaete Capitella sp. I. Mar Ecol Prog Ser 216:119-127

Vasquez-Cardenas D, van de Vossenberg J, Polerecky L, Malkin SY and others (2015) Microbial carbon metabolism associated with electrogenic sulfur oxidation in coastal sediments. Int $J$ Syst Evol Microbiol 9: 1966-1978

Vestal JR, White DC (1989) Lipid analysis in microbial ecology. Bioscience 39:535-541

Webster G, Watt LC, Rinna J, Fry JC and others (2006) A comparison of stable-isotope probing of DNA and phospholipid fatty acids to study prokaryotic functional diversity in sulfate-reducing marine sediment enrichment slurries. Environ Microbiol 8:1575-1589

Yazdani Foshtomi M, Braeckman U, Derycke S, Sapp M and others (2015) The link between microbial diversity and nitrogen cycling in marine sediments is modulated by macrofaunal bioturbation. PLoS ONE 10:e0130116

Submitted: May 19, 2015; Accepted: February 29, 2016 Proofs received from author(s): April 29, 2016 